\title{
Multifunctional Magnetic Mesoporous Silica Nanoagents for in vivo Enzyme-Responsive Drug Delivery and MR Imaging
}

\author{
Erdong $\mathrm{Li}^{1}$, Yanmei Yang ${ }^{2,3}{ }^{\bowtie}$, Guangyu $\mathrm{Hao}^{4}$, Xuan Yi, ${ }^{2}$ Shaohua Zhang, ${ }^{2}$ Yue Pan ${ }^{1,5}{ }^{\bowtie}$, Bengang Xing ${ }^{6}$, \\ Mingyuan $\mathrm{Gao}^{2}$ \\ 1. State and Local Joint Engineering Laboratory for Novel Functional Polymeric Materials, College of Chemistry, Chemical Engineering and Materials Science, Soochow \\ University, Suzhou, 215123, China. \\ 2. State Key Laboratory of Radiation Medicine and Protection, School for Radiological and Interdisciplinary Sciences (RAD-X) and Collaborative Innovation Center of \\ Radiological Medicine of Jiangsu Higher Education Institutions, Soochow University, Suzhou, 215123, China. \\ 3. College of Chemistry, Chemical Engineering and Materials Science, Collaborative Innovation Center of Functionalized Probes for Chemical Imaging in Universities of \\ Shandong, Key Laboratory of Molecular and Nano Probes, Ministry of Education, Institute of Biomedical Sciences, Shandong Normal University, Jinan 250014, China. \\ 4. Imaging Center, The First Affiliated Hospital of Soochow University, Suzhou, China. \\ 5. Guangdong Provincial Key Laboratory of Malignant Tumor Epigenetics and Gene Regulation, Sun Yat-Sen Memorial Hospital, Sun Yat-Sen University, Guangzhou, \\ 510120, China. \\ 6. Division of Chemistry \& Biological Chemistry, School of Physical \& Mathematical Sciences, Nanyang Technological University, Singapore 637371, Republic of \\ Singapore. \\ $\triangle$ Corresponding authors: panyueps@gmail.com,yym@suda.edu.cn
}

(c) Ivyspring International Publisher. This is an open access article distributed under the terms of the Creative Commons Attribution (CC BY-NC) license (https://creativecommons.org/licenses/by-nc/4.0/). See http://ivyspring.com/terms for full terms and conditions.

Received: 2018.02.17; Accepted: 2018.05.11; Published: 2018.05.23

\begin{abstract}
In this study, we report novel multifunctional nanoagents for in vivo enzyme-responsive anticancer drug delivery and magnetic resonance imaging (MRI), based on mesoporous silica coated iron oxide nanoparticles ( $\left.\mathrm{Fe}_{3} \mathrm{O}_{4} @ M S N s\right)$. The anticancer drug, DOX, was encapsulated in the porous cavities with a MMP-2 enzyme responsive peptide being covalently linked to the nanoparticles surface. The in vitro experiment results indicated that the enzyme responsive nanoagents own high specificity for controlled drug release in the cell line with high MMP-2 expression. Furthermore, the targeted delivery of the nanoagents to the tumor site purpose has been successfully achieved through magnet-guided nanocarrier accumulation by utilizing the magnetic properties of the $\mathrm{Fe}_{3} \mathrm{O}_{4}$ nanocores, which resulted in efficient inhibition of the tumor growth. Additionally, these novel nanoagents can also be used as MRI agent for the real-time diagnosis the tumor treatment process of living animals. Taking the advantages of high specificity, controllable drug release and real-time MRI imaging, we believe these multifunctional nanoagents could also be used as a general platform for the design of stimulus-responsive multifunctional nanomaterials for the aim of accurate diagnosis and efficient treatment of other diseases.
\end{abstract}

Key words: iron oxide, enzyme-responsive drug delivery, tumor inhibition

\section{Introduction}

Cancer keeps being one of the extremely complex diseases that challenge the lives of human beings in all age groups [1]. So far, several standard approaches have been well developed for cancer therapy, such as chemotherapies and surgery [2]. Although traditional chemotherapy has been proved to be effective, it faces the primary concerns of systematic toxicity of drug molecules and poor tumor selectivity, which cause damage to healthy tissues [3].
Accounting targeted chemotherapy, the major issue is its incapability to specially deliver the sufficient amount of therapeutic reagents to the disease area [4]. Although surgery is the preferred treatment method for many cancers, it is difficult to unambiguously distinguish between normal and cancer tissues during treatment. It remains to be a big challenge to achieve complete removal of cancer tissues and minimize recurrences. Thus, the rational design that can 
effectively deliver sufficient drug molecules to the disease site has always attracted enormous research interest.

To date, various strategies have been developed for targeted drug delivery through controlling the drug release to the tumor [5-7]. Taking the advantages of nanotechnology, many different kinds of bio-inspired and stimuli-responsive (such as $\mathrm{pH}$, ionic strength, light, enzyme, etc) systems have been exploited for therapeutic agent delivery [8-11]. As well known, enzymes play critical roles in activating almost all biological processes, thus the dysregulation of enzyme expression and activity underpins the pathology of many diseases, which could be employed for the design of enzyme-responsive drug delivery system [12-14]. The integration of nanomaterials with responsive enzymatic system can endow the formulations of bio-specificity and selectivity, constituting new possibilities for promising applications in targeted drug delivery [15]. Especially for tumor treatment, those enzymes that intimately associated with tumor invasiveness and metastasis (such as protease and phospholipases) are important candidates to be utilized for the design of tumor-targeted drug delivery systems [16-20].

Matrix metalloproteinases (MMPs), as one of the important internal physiological changes of the tumor microenvironment, is such an indicator protein that is overexpressed in almost all tumors [21]. It has been demonstrated that MMP-2 triggered nanocarriers can be used for cancer imaging and therapy with high specificity and sensitivity $[22,23]$. For instance, Peng et al. designed a N-(2-hydroxypropyl)-methacrylamide (HPMA) copolymer system with MMP-2 cleavable spacer for targeted drug delivery of prostate cancer therapy [24]. Zou and co-workers demonstrated a MMP-2 responsive system for tumor drug release by using gelatin layer blocked nanocarrier [25]. However, the drug delivery platforms employed in these designs typically require complicated synthetic processes which become the main obstacle for their practical applications. Accounting these, the rational design of a simple and effective strategy that enables tumor-targeted therapy is highly expected.

So far, the mesoporous silica-related nanostructures have attracted great research interest in therapeutic applications because of their active surface for drug loading, good biocompatibility and convenient surface modification [26-28]. Accordingly, enormous research efforts have been devoted to the advancement of multifunctional mesoporous silica-based nanoplatforms (MSNs) for therapeutic applications. For instance, using $\beta-C D$ capped MSNs, $\mathrm{Hu}$ et al. proposed a ROS-triggered drug release system for enhanced chemotherapy [29]. Zhao et al. have demonstrated that the mitochondria targeted MSNs can effectively deliver the anticancer agent, a-tocopheryl succinate, with enhanced efficiency.[30] Zhao's group has also demonstrated that the dyes loaded inside MSNs can be effectively protected from nucleophilic attack, thus the hybrid presents significant potential for fluorescence imaging in vitro $[30,31]$.

Taking the aforementioned advantages of MSNs, in this study, we propose a new strategy for targeted drug delivery based on the multifunctional mesoporous silica coated iron oxide nanoagents $\left(\mathrm{Fe}_{3} \mathrm{O}_{4} @ \mathrm{MSNs}\right.$, Figure 1). The surface of $\mathrm{Fe}_{3} \mathrm{O}_{4} @ \mathrm{MSNs}$ was further modified by the MMP-2 responded peptide substrate (PLGVR). We demonstrate that this peptide- $\mathrm{Fe}_{3} \mathrm{O}_{4} @ \mathrm{MSN}$ drug delivery system enables the real-time monitoring of the cellular drug release in living conditions as well as for fluorescence imaging and magnetic resonance imaging (MRI). In vivo animal tests on tumor-bearing mouse model further reveal the efficient and targeted drug release at the tumor site. Compare with previously published drug delivery carriers that used for MRI, fluorescence imaging and drug delivery [32-34], $\mathrm{Fe}_{3} \mathrm{O}_{4} @ \mathrm{MSNs}$ provide magnetic targeting as a complementary mean nanoparticles' enrichment in the tumor area, whereas

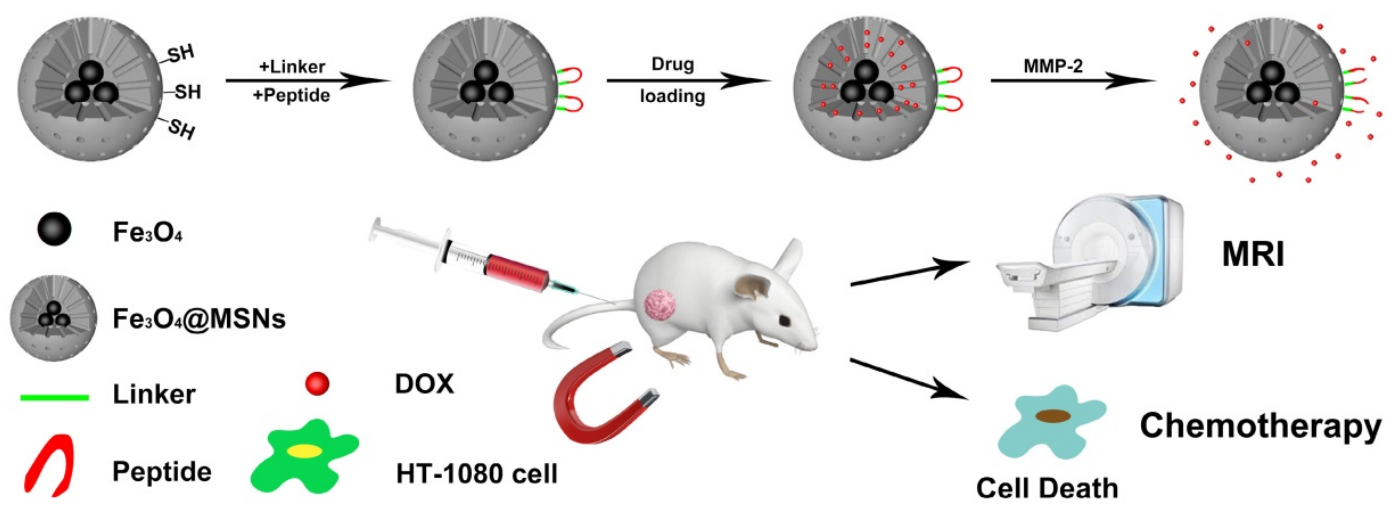

Figure 1. Schematic illustration of peptide- $\mathrm{Fe}_{3} \mathrm{O}_{4} @ M S N$ s for enzyme-responsive drug delivery and MRI 
effective enrichment is of great importance to drug carriers. In addition, these multifunctional nanoagents could also be used as a general platform for the design and fabrication of enzyme responsive functional nanomaterials that offer new possibilities to diagnose and combat with cancer.

\section{Materials and Methods}

\section{Materials}

Sodium oleate $(>95 \%)$, iron chloride $(>99 \%)$, oleic acid $(>99 \%)$, ethyl acetate $(>99 \%), \quad N$, N-Dimethylformamide (DMF) (>99\%) and dimethyl sulfoxide (DMSO) $(>99 \%)$ were purchased from Sinopharm group CO. Ltd. Cetyltrimethylammonium bromide $(\mathrm{CTAB})$ was purchased from Sigma-Aldrich. Tetraethyl orthosilicate (TEOS) (>99\%), (3-mercaptopropyl)-methyl dimethoxysilane (>99\%), 1-octadecene (ODE) (90\%), 3-(Maleimido) propionic acid N-hydroxysuccinimide ester (NHS-linker) (99\%) and doxorubicin (DOX) $(>98 \%)$ were purchased from Aladdin. MMP-2 peptide (Gly-Gly-Pro-Leu-Gly-ValArg-Gly-Lys) (96.17\%) was provided by China Peptides Co., Ltd.

\section{Synthesis of $\mathrm{Fe}_{3} \mathrm{O}_{4} @ M S N s$}

Oleic acid coated $\mathrm{Fe}_{3} \mathrm{O}_{4}$ nanoparticles were prepared following the method [35]. In typical experiments, iron oleate $(1.0 \mathrm{~g})$ and oleic acid (177.3 $\mu \mathrm{L})$ were added into ODE $(7.1 \mathrm{~mL})$. The mixture was stirred at $120{ }^{\circ} \mathrm{C}$ for $1 \mathrm{~h}$ and then heated to $312{ }^{\circ} \mathrm{C}$ under $\mathrm{N}_{2}$ atmosphere followed by maintained for another $1 \mathrm{~h}$. After cooling down to room temperature and precipitation through adding extra ethanol, the $\mathrm{Fe}_{3} \mathrm{O}_{4}$ nanoparticles were collected by centrifugation. The products were then washed with hexane and ethanol and stored for the further use.

To transfer $\mathrm{Fe}_{3} \mathrm{O}_{4}$ nanoparticles into aqueous phase, dispersion of nanoparticles $(1.0 \mathrm{~mL}$ in chloroform) was mixed with the CTAB solution $(0.4 \mathrm{~g}$ in $20 \mathrm{~mL}$ DI water) and then stirred at $60^{\circ} \mathrm{C}$ for $3 \mathrm{~h}$. After that, the mixture was filtered through $0.44 \mu \mathrm{m}$ syringe filter to remove large aggregates. The filtered solution $(2.5 \mathrm{~mL})$ and $\mathrm{NaOH}(2 \mathrm{M}, 175 \mu \mathrm{L})$ solution were diluted with deionized water $(21.5 \mathrm{~mL})$, followed by heating to $70{ }^{\circ} \mathrm{C}$. After stirring for $10 \mathrm{~min}$ at $70{ }^{\circ} \mathrm{C}$, TEOS $(150 \mu \mathrm{L})$ and ethyl acetate $(1.5 \mathrm{~mL})$ were added into the mixture. After stirring for another $5 \mathrm{~min}$, (3-mercaptopropyl)-methyl dimethoxysilane $(12.5 \mu \mathrm{L})$ was added to the mixture. The $\mathrm{Fe}_{3} \mathrm{O}_{4} @ \mathrm{MSN}$ s were collected after $3 \mathrm{~h}$ washed by ethanol for three times. Then precipitation was re-dispersed in ethanol and mixed with $\mathrm{NH}_{4} \mathrm{NO}_{3}(80$ $\mathrm{mg}$ ) at $60^{\circ} \mathrm{C}$ and stirred for $2 \mathrm{~h}$ to remove the excess $\mathrm{CTAB}$. The morphology and size distribution of those particles were examined using a transmission electron microscope (Tecnai G220, FEI, USA) at an acceleration voltage of $200 \mathrm{kV}$. MR relaxometry of the magnetic $\mathrm{Fe}_{3} \mathrm{O}_{4} @$ MSNs particles was performed using a $3.0 \mathrm{~T}$ MRI equipment (GE 3.0 T Signa) and $T_{2}$ relaxivity was deduced from inverse $T_{2}$ as a function of iron concentrations.

\section{Synthesis of peptide-Fe $\mathrm{O}_{\mathbf{4}} @ \mathrm{MSNs}$}

$\mathrm{Fe}_{3} \mathrm{O}_{4} @ \mathrm{MSNs}(17.0 \mathrm{mg})$ and NHS-linker (23.5 $\mathrm{mg})$ were mixed with DMF $(360 \mu \mathrm{L})$ and followed by adding DIPEA $(15 \mu \mathrm{L})$. The reaction was left to stir for $12 \mathrm{~h}$ at room temperature. The product was collected through centrifugation and washed with ethanol for three times. After being re-dispersed in DMF $(360 \mu \mathrm{L})$, the peptide $(15.0 \mathrm{mg})$ and DIPEA $(10 \mu \mathrm{L})$ was added and stirred for another $12 \mathrm{~h}$. After that, the reaction solution was centrifuged to remove unreacted reactant and then washed with ethanol/water (1:1) for three times. The final product was suspended in dried dimethyl sulfoxide (DMSO) for further use.

\section{Drug loading on peptide-Fe $\mathrm{O}_{4} @ M S N s$ nanocarriers}

$200 \mu \mathrm{L}$ DOX in DMSO $(10 \mathrm{mg} / \mathrm{mL})$ was mixed with $3.7 \mathrm{mg}$ peptide- $\mathrm{Fe}_{3} \mathrm{O}_{4} @ \mathrm{MSNs}$. The mixture was stirred for $24 \mathrm{~h}$ in the dark environment. The nanoparticles were collected by centrifugation and the precipitation was washed with PBS buffer for three times to remove the excess DOX. All the supernatant was collected for measuring the UV absorbance of DOX, which was used to evaluate the loading efficiency of DOX by peptide- $\mathrm{Fe}_{3} \mathrm{O}_{4} @ \mathrm{MSN}$. The final product was abbreviated as peptide- $\mathrm{Fe}_{3} \mathrm{O}_{4} @ \mathrm{MSNs} /$ DOX.

\section{Drug release from peptide- $\mathrm{Fe}_{3} \mathrm{O}_{4} @ M S N s / D O X$}

$2 \mu \mathrm{L}$ of MMP-2 enzyme stock solution (200 $\mathrm{ng} / \mathrm{mL}$ ) was added to each vial containing peptide- $\mathrm{Fe}_{3} \mathrm{O}_{4} @ \mathrm{MSNs} / \mathrm{DOX}$ solution of Tris buffer (10 $\mu \mathrm{M}, 20 \mu \mathrm{L})$ and incubated for a serious of times (20 $\mathrm{min}, 40 \mathrm{~min}, 60 \mathrm{~min}, 80 \mathrm{~min}, 100 \mathrm{~min}, 120 \mathrm{~min}, 140$ $\mathrm{min}, 160 \mathrm{~min}$ ) at $37{ }^{\circ} \mathrm{C}$. After centrifugation, the supernatant was collected and then diluted with PBS buffer $(80 \mu \mathrm{L})$. Fluorescence spectroscopic studies were performed at an excitation wavelength of 480 nm. Additionally, nanocarriers without peptide capping or the nanocarriers with additional inhibitor, were also explored as control experiments.

\section{MTT assay}

HT-1080 and NIH/3T3 cells were cultured in a 96-well culture plate at a density of $1 \times 10^{4}$ cells per well under $5 \% \mathrm{CO}_{2}$ atmosphere condition at $37^{\circ} \mathrm{C}$ for $24 \mathrm{~h}$. Then, the cells were washed with PBS and incubated with $\mathrm{Fe}_{3} \mathrm{O}_{4} @ \mathrm{MSNs}$, peptide- $\mathrm{Fe}_{3} \mathrm{O}_{4} @ \mathrm{MSNs} /$ 
DOX, and free DOX (DOX concentration: $5 \mu \mathrm{M}$ ), respectively. After incubation for $2 \mathrm{~h}, 4 \mathrm{~h}, 8 \mathrm{~h}, 12 \mathrm{~h}$ and $24 \mathrm{~h}$, the original medium was replaced by $100 \mu \mathrm{L}$ medium containing $10 \mu \mathrm{L}$ MTT solution $(5 \mathrm{mg} / \mathrm{mL})$ and incubated for another $4 \mathrm{~h}$. Then the medium was removed and followed by adding $100 \mu \mathrm{L}$ DMSO into each well to dissolve the precipitate. The absorption of each solution was measured at $490 \mathrm{~nm}$ on a microplate reader (Synergy NEO).

\section{Laser scanning confocal microscopy}

HT-1080 and NIH/3T3 cells were seeded to confocal dishes with a density of $1.5 \times 10^{5}$ per dish, respectively. $1 \mathrm{~mL}$ medium containing peptide- $\mathrm{Fe}_{3} \mathrm{O}_{4} @ \mathrm{MSNs} / \mathrm{DOX}$ or free DOX (DOX concentration: $5 \mu \mathrm{M}$ ) was added to each dish. After incubation for $4 \mathrm{~h}, 8 \mathrm{~h}$ and $12 \mathrm{~h}$, the culture medium was replaced with PBS buffer. Then the Hoechst 33342 $(10 \mu \mathrm{g} / \mathrm{mL})$ was added to stain the nuclei of cells. The confocal images were obtained using a laser scanning confocal microscope (OLYMPUS FV120).

\section{Tumor-bearing mice model}

Animal experiments were conducted strictly following the guidelines of the Institutional Animal Care and Use Ethical Committee of Soochow University. Female nude mice of 5 weeks old were purchased from Shanghai SLAC Laboratory Animal Co. Ltd (Shanghai, China). The tumor model was established by subcutaneously injecting $100 \mu \mathrm{L}$ PBS containing $3 \times 10^{6}$ HT- 1080 cells into the back of each mouse. After around 2 weeks, the mice bearing 100 $\mathrm{mm}^{3}$ tumors were selected for following experiments.

\section{Biodistribution analysis}

Tumor-bearing mice were randomly divided into two groups, which were intravenously injected with (1) peptide- $\mathrm{Fe}_{3} \mathrm{O}_{4} @ \mathrm{MSNs} / \mathrm{DOX}(2 \mathrm{mg} / \mathrm{mL}, 200$ $\mu \mathrm{L} ; 1.6 \mathrm{mg} / \mathrm{kg}$ ), and (2) peptide- $\mathrm{Fe}_{3} \mathrm{O}_{4} @ \mathrm{MSNs} / \mathrm{DOX}$ (2 $\mathrm{mg} / \mathrm{mL}, 200 \mu \mathrm{L}, 1.6 \mathrm{mg} / \mathrm{kg}$ ) with magnet treatment, respectively. For the bio-distribution assay: the mice were humanely sacrificed after $8 \mathrm{~h}$. After that, the main organs, tissues and tumors were collected, wet-weighed, and dissolved in the digesting solution $\left(\mathrm{HNO}_{3}: \mathrm{H}_{2} \mathrm{O}_{2}\right.$ of 2:1 by volume). The content of iron ions in each tissue was determined by ICP-OES.

\section{In vivo $M R$ imaging}

Tumor-bearing mice were injected with peptide- $\mathrm{Fe}_{3} \mathrm{O}_{4} @ \mathrm{MSNs} / \mathrm{DOX}(2 \mathrm{mg} / \mathrm{mL}, 200 \mu \mathrm{L} ; 1.6$ $\mathrm{mg} / \mathrm{kg}$ equiv DOX) via tail vein. In addition, magnetic targeting was applied to half of these mice. The MR images were captured by a $T_{2}$-weighted spin-echo sequence (TR/TE $=4000 / 108 \mathrm{~ms}$; slice thickness, $2 \mathrm{~mm}$; slice spacing, $1 \mathrm{~mm}$; matrix, $256 \times$
256; FOV , $8 \mathrm{~cm} \times 8 \mathrm{~cm}$ ). Signal variation was observed after the injection of nanocarriers for $0.5 \mathrm{~h}, 1 \mathrm{~h}, 2 \mathrm{~h}$, and $3 \mathrm{~h}$.

\section{In vivo chemotherapy}

The tumor-bearing mice were randomly divided into 3 groups (each group has 5 mice): (1) control group (treated with $\mathrm{PBS}$ ), (2) peptide- $\mathrm{Fe}_{3} \mathrm{O}_{4} @ \mathrm{MSNs} /$ DOX group, and (3) peptide- $\mathrm{Fe}_{3} \mathrm{O}_{4} @ \mathrm{MSNs} / \mathrm{DOX} \&$ magnet group. Mice in experimental groups were injected with nanocarriers $(2 \mathrm{mg} / \mathrm{mL}, 200 \mu \mathrm{L}, 1.6$ $\mathrm{mg} / \mathrm{kg}$ equiv DOX, freshly prepared) through the tail vein every two days. For peptide- $\mathrm{Fe}_{3} \mathrm{O}_{4} @ \mathrm{MSNs} / \mathrm{DOX}$ $\&$ magnet group, magnetic treatment at the tumor site was conducted for $8 \mathrm{~h}$ after each injection. The body weight and tumor size of each mouse were measured every two days. The tumor volumetric size was calculated according to the formula: $\mathrm{V}=\mathrm{LW}^{2} / 2$ (V: the volume of tumor, $\mathrm{L}$ : the maximum length of the tumor, W: the minimum width of the tumor). After 3 weeks of treatment, all mice were sacrificed and main organs were collected for histological analysis.

\section{Histological analysis}

For the hematoxylin and eosin (H\&E) staining experiment, the major organs (heart, liver, spleen, lung, and kidney) that were collected from previous step were harvested, dipped in $10 \%$ formalin and processed routinely into paraffin. Then the $5 \mu \mathrm{M}$ thick slices were prepared and stained with H\&E for histological analysis.

\section{Results and Discussion}

The core-shell $\mathrm{Fe}_{3} \mathrm{O}_{4} @ \mathrm{MSN}$ s was synthesized via the sol-gel reaction method $[36,37]$. The hydrophobic spherical $\mathrm{Fe}_{3} \mathrm{O}_{4}$ nanoparticles were prepared following the method [35]. To enhance the biocompatibility and the subsequent drug loading efficiency, the $\mathrm{Fe}_{3} \mathrm{O}_{4}$ nanoparticles obtained were coated with thiol-modified mesoporous silica shell. TEM was used to characterize the morphologies of $\mathrm{Fe}_{3} \mathrm{O}_{4}$ and $\mathrm{Fe}_{3} \mathrm{O}_{4} @ \mathrm{MSN}$ nanoparticles. As shown in Figure $2 \mathrm{a}$ and $2 \mathrm{~b}, \mathrm{Fe}_{3} \mathrm{O}_{4}$ and $\mathrm{Fe}_{3} \mathrm{O}_{4} @ \mathrm{MSN}$ had a spherical shape and uniform size. Average sizes of $\mathrm{Fe}_{3} \mathrm{O}_{4}$ and $\mathrm{Fe}_{3} \mathrm{O}_{4} @ M S N$ s were determined by counting more than 200 nanocrystals per sample, which were $14 \mathrm{~nm}$ and $114 \mathrm{~nm}$, respectively (Figure S1a and 1b). The dynamic light scattering (DLS) measurements, shown in Figure S1c, revealed that the hydrodynamic size of $\mathrm{Fe}_{3} \mathrm{O}_{4} @ \mathrm{MSN}$ dispersed in PBS was around 600 $\mathrm{nm}$. More importantly, after three rounds of testing, the location of peaks varied slightly, meaning that $\mathrm{Fe}_{3} \mathrm{O}_{4} @ \mathrm{MSN}$ had excellent colloidal stability, which was very important for their biomedical applications. It is clear that the silica coating layer is around $50 \mathrm{~nm}$ 

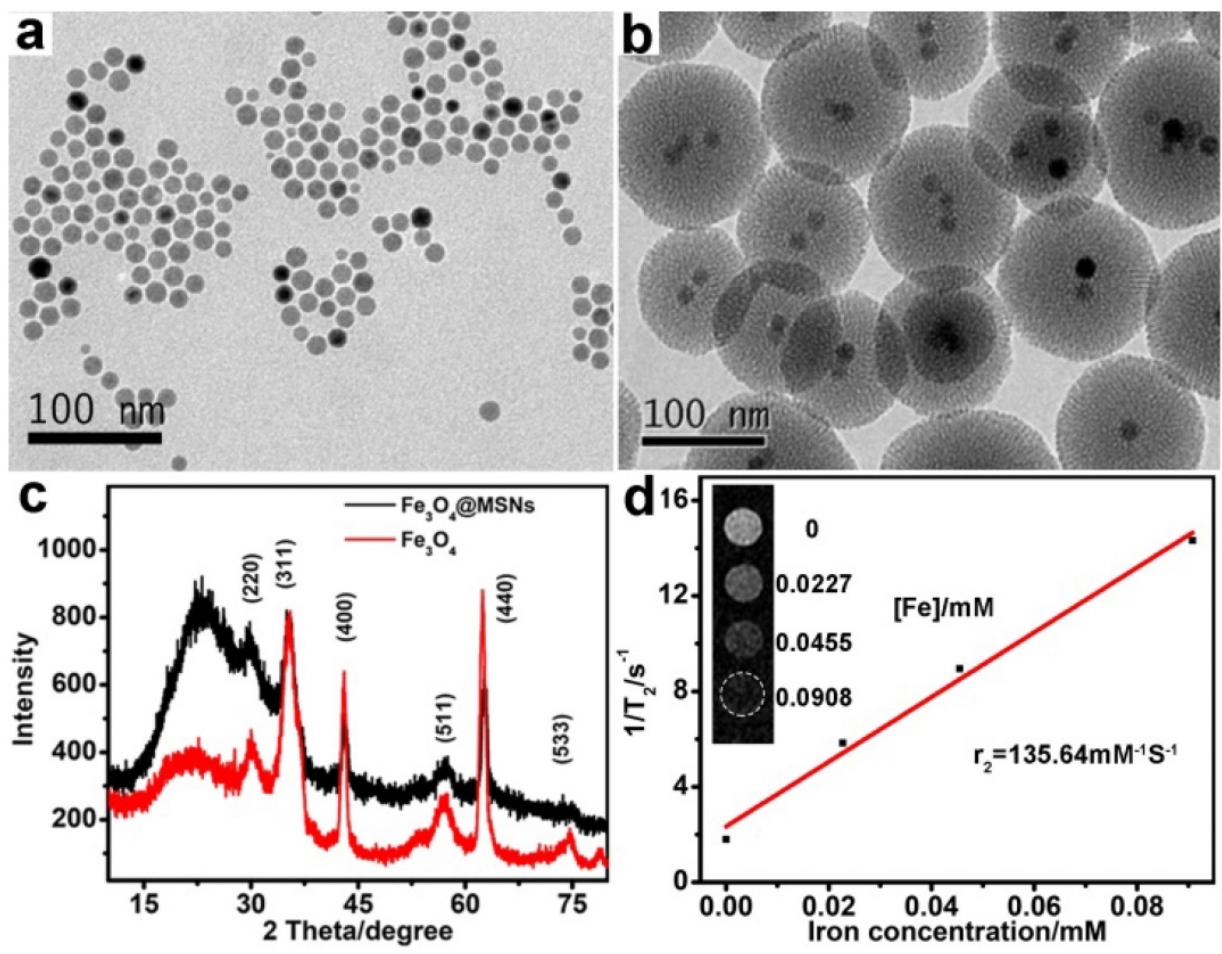

Figure 2. TEM images of (a) $\mathrm{Fe}_{3} \mathrm{O}_{4}$ and (b) $\mathrm{Fe}_{3} \mathrm{O}_{4} @ M S N s$. (c) XRD pattern of $\mathrm{Fe}_{3} \mathrm{O}_{4}$ and $\mathrm{Fe}_{3} \mathrm{O}_{4} @ M S N_{s}$. (d) $\mathrm{T}_{2}$-weight MR images of Fe3 $\mathrm{O}_{4} @ M S \mathrm{Ns}$ at different iron concentration and plot of $T_{2} 2^{-1}$ versus iron concentration. Transverse $\left(r_{2}\right)$ relaxivity was derived from linear flitting of the data.

thick, which provides an attractive cavity for drug loading. The phase purity of the as-synthesized $\mathrm{Fe}_{3} \mathrm{O}_{4}$ and $\mathrm{Fe}_{3} \mathrm{O}_{4} @ \mathrm{MSN}$ were further characterized through XRD (Figure 2c), which indicated that pure $\mathrm{Fe}_{3} \mathrm{O}_{4}$ was obtained (PDF\# 19-0629) [38] and the successful coating of $\mathrm{Fe}_{3} \mathrm{O}_{4}$ by amorphous silica. The contrast effect of the $\mathrm{Fe}_{3} \mathrm{O}_{4} @ \mathrm{MSN}$ was verified by measuring transverse $\left(T_{2}\right)$ relaxation times of dispersed nanostructures on the 3.0 T MRI equipment (TR 4240 ms; TE $108 \mathrm{~ms}$; slice thickness, $1 \mathrm{~mm}$; slice spacing, 1 mm; matrix, $256 \times 256$; FOV $8 \mathrm{~cm} \times 8 \mathrm{~cm}$ ). The $T_{2}$-weight MR signals were significantly enhanced with the rise of concentration of nanomaterials. The specific relaxivity value $\left(r_{2}\right)$ was calculated to be 135.6 $\mathrm{mM}^{-1} \mathrm{~s}^{-1}$ (Figure $2 \mathrm{~d}$ ), indicating that the $\mathrm{Fe}_{3} \mathrm{O}_{4} @ \mathrm{MSNs}$ can serve as sensitive contrast agent for MRI [39].

For the purpose of efficient drug encapsulation and enhanced tumor targeting of the nanocarriers, the surface of the silica shell was further covalently capped with the MMP-2 substrate peptide (GGPLGVRGK). The drug loading capability of this peptide- $\mathrm{Fe}_{3} \mathrm{O}_{4} @ \mathrm{MSN}$ s platform was evaluated with the commercial anticancer drug, DOX. Typically, the peptide- $\mathrm{Fe}_{3} \mathrm{O}_{4} @ \mathrm{MSN}$ was soaked in a DOX/DMSO mixed solution for $24 \mathrm{~h}$, then the nanocarriers were centrifuged to remove the unbound DOX and the precipitate was further washed by PBS $(10 \mathrm{mM}$, $\mathrm{pH}=7.2)$. The loading efficiency was determined by the difference in the UV-Vis absorbance of DOX at 480 $\mathrm{nm}$, which was calculated to be $12.2 \%(\mathrm{w} / \mathrm{w})$. This value was comparable with the results reported previously [33, 40]. Generally, DOX exhibited a red fluorescence emission under excitation at $480 \mathrm{~nm}$, while peptide- $\mathrm{Fe}_{3} \mathrm{O}_{4} @ \mathrm{MSN} / \mathrm{DOX}$ showed almost undetectable fluorescence (Figure 3a). Similarly, after centrifugation, the tube containing peptide- $\mathrm{Fe}_{3} \mathrm{O}_{4}$ $@$ MSNs/DOX showed significantly weaker fluorescent signal compared with the tube with free DOX (Figure 3a, insert graph). This is because the fluorescence is quenched when the DOX molecules were encapsulated into mesoporous silica shell, because of self-quenching [10,41].

To verify the efficiency of this enzyme-responsive drug delivery system, the drug release test was experimentally carried out under physiological condition (Tris buffer, $37^{\circ} \mathrm{C}$ ). The following samples were prepared as control: (1) $\mathrm{Fe}_{3} \mathrm{O}_{4} @ M S N s / D O X$ sample without peptide capsulation; (2) peptide- $\mathrm{Fe}_{3} \mathrm{O}_{4} @ \mathrm{MSNs} / \mathrm{DOX}$ without enzyme and (3) the peptide- $\mathrm{Fe}_{3} \mathrm{O}_{4} @ \mathrm{MSN} / \mathrm{DOX}$ with enzyme and inhibitor (prinomastat hydrochloride). As shown in Figure 3b, in the first $20 \mathrm{~min}$, the release rate of DOX from $\mathrm{Fe}_{3} \mathrm{O}_{4} @ \mathrm{MSN} / \mathrm{DOX}$ increased dramatically which was much higher than other samples, because the porous surface was not blocked by anything. When it came to peptide$\mathrm{Fe}_{3} \mathrm{O}_{4} @ \mathrm{MSNs} / \mathrm{DOX}$ with enzyme, the release rate was pretty low in the first $20 \mathrm{~min}$. However, from $20 \mathrm{~min}$ to $80 \mathrm{~min}$, the profile underwent a quick increase and nearly $70 \%$ (comparable to that of $\mathrm{Fe}_{3} \mathrm{O}_{4} @ \mathrm{MSNs}$ / DOX) of DOX escaped from peptide- $\mathrm{Fe}_{3} \mathrm{O}_{4} @ \mathrm{MSNs} /$ DOX. This is attributed to the MMP-2 enzyme which 
cleaved the blocked peptide. In contrast, for the peptide- $\mathrm{Fe}_{3} \mathrm{O}_{4} @ \mathrm{MSN} / \mathrm{DOX}$ sample in the presence of MMP-2 and inhibitor, only about $17 \%$ DOX was released even after $160 \mathrm{~min}$. This value is very close to the release ratio of peptide- $\mathrm{Fe}_{3} \mathrm{O}_{4} @ \mathrm{MSNs} / \mathrm{DOX}$ only (about $15.7 \%$ ). In addition, the fluorescent images of peptide- $\mathrm{Fe}_{3} \mathrm{O}_{4} @ \mathrm{MSN} / \mathrm{DOX}$ solution incubated with MMP-2 enzyme or MMP-2 and enzyme inhibitor at different time were also exhibited in the insert of Figure $3 \mathrm{~b}$. It is clear that, for samples treated with MMP-2 only, the strength of fluorescence signal gradually increased with respect to incubation time. In contrast, very weak signal intensity change was detected for samples treated with MMP-2 and inhibitor together. These results solidly support the high performance of this peptide- $\mathrm{Fe}_{3} \mathrm{O}_{4} @ \mathrm{MSNs} / \mathrm{DOX}$ nanocarrier system for enzyme-responsive drug release, both in release efficiency and enzyme sensitivity.
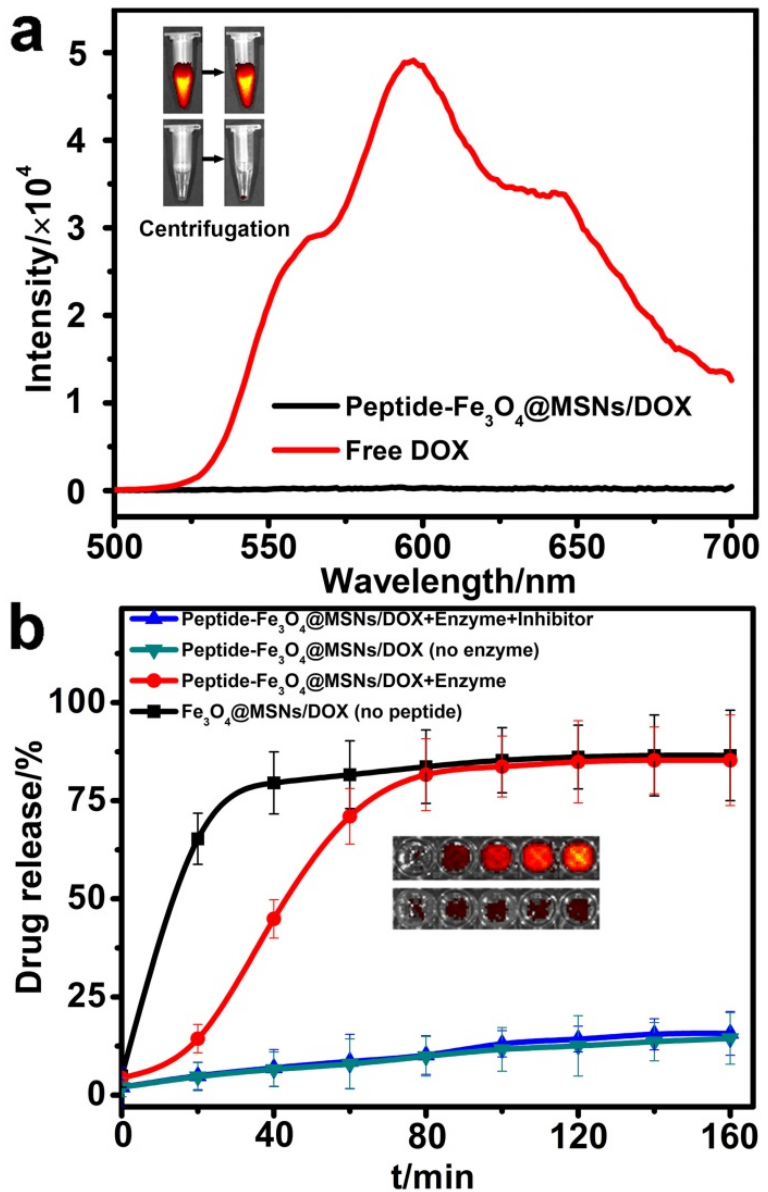

Figure 3. (a) Fluorescence spectrum of free $\mathrm{DOX}$ and peptide- $-\mathrm{Fe}_{3} \mathrm{O}_{4} @ M S N s / D O X$. Inset: corresponding fluorescence images of free DOX (upper) and peptide- $\mathrm{Fe}_{3} \mathrm{O}_{4} @ M S N s / D O X$ (nether) before (left) and after (right) centrifugation. (b) Enzyme-responsive release profiles of DOX from $\mathrm{Fe}_{3} \mathrm{O}_{4} @ M S N s / D O X$, peptide- $-\mathrm{Fe}_{3} \mathrm{O}_{4} @ M S N s / D O X$ (with and without MMP-2), peptide- $\mathrm{Fe}_{3} \mathrm{O}_{4} @ M S N s /$ DOX with MMP-2 and MMP-2 inhibitor. Inset: fluorescence images of peptide- $\mathrm{Fe}_{3} \mathrm{O}_{4} @ M S N s$ \& MMP-2 (upper) and peptide-Fe $\mathrm{O}_{4} @ M S N s$ \& MMP-2 \& inhibitor (nether) after different time $(20 \mathrm{~min}, 40 \mathrm{~min}, 80 \mathrm{~min}, 120 \mathrm{~min}, 160 \mathrm{~min}$, from left to right).
To assess the biocompatibility and the anticancer effect of the peptide- $\mathrm{Fe}_{3} \mathrm{O}_{4} @ \mathrm{MSNs} / \mathrm{DOX}$ system, two kinds of cells, HT-1080 (representing tumor cells) and $\mathrm{NIH} / 3 \mathrm{~T} 3$ (representing normal cells) were employed for cellular cytotoxicity test. The methylthiazoletetrazolium assay (MTT) was adopted to evaluate the anticancer effect. Typically, the HT-1080 cells and $\mathrm{NIH} / 3 \mathrm{~T} 3$ cells were incubated with $\mathrm{Fe}_{3} \mathrm{O}_{4} @ \mathrm{MSNs}$, peptide- $\mathrm{Fe}_{3} \mathrm{O}_{4} @ \mathrm{MSN} / \mathrm{DOX}$ and free DOX for $2 \mathrm{~h}, 4 \mathrm{~h}$, $8 \mathrm{~h}, 12 \mathrm{~h}$ and $24 \mathrm{~h}$, respectively. The doses of DOX were kept being same between the peptide$\mathrm{Fe}_{3} \mathrm{O}_{4} @ M S N s / D O X$ and free DOX. HT-1080 and $\mathrm{NIH} / 3 \mathrm{~T} 3$ cells without any treatment were selected as controls in this study. From Figure 4a and $4 b$, as high as $93.9 \%$ (HT-1080) and $92.9 \%$ (NIH/3T3) of cell viability were detected when they were cultured with $\mathrm{Fe}_{3} \mathrm{O}_{4} @ \mathrm{MSNs}$ even after $24 \mathrm{~h}$, indicating the considerably good biocompatibility of $\mathrm{Fe}_{3} \mathrm{O}_{4} @ \mathrm{MSNs}$. When NIH/3T3 cells were cultured with peptide- $\mathrm{Fe}_{3} \mathrm{O}_{4} @ \mathrm{MSNs} / \mathrm{DOX}$, the cell viability still reached $80 \%$ after $24 \mathrm{~h}$, which was higher than that treated with free DOX (46.4\%, Figure 4a). While for HT-1080 cells treated with both peptide$\mathrm{Fe}_{3} \mathrm{O}_{4} @ M S N s / D O X$ and free DOX, the cell viabilities were comparable, about $50 \%$ and $46 \%$ respectively (Figure $4 \mathrm{~b}$ ), which indicated the nanocarriers got a favourable selectivity between normal cells and cancer cells.

Utilizing the fluorescence property of DOX molecules, the nanocarrier distribution and drug release process in living cells were monitored by confocal fluorescence imaging. HT-1080 cells were used as representatives which were incubated with free DOX, peptide- $\mathrm{Fe}_{3} \mathrm{O}_{4} @ \mathrm{MSNs} / \mathrm{DOX}$ and peptide$\mathrm{Fe}_{3} \mathrm{O}_{4} @ \mathrm{MSNs} / \mathrm{DOX}+$ inhibitor. The intracellular distribution of DOX and morphology change of cells nuclei were monitored with respect to incubation time. After incubation with free DOX for $4 \mathrm{~h}$ (Figure. $4 \mathrm{c})$, clear deformation was detected for the morphology of cells and their nuclei. When the incubation time was prolonged to $8 \mathrm{~h}$ and $12 \mathrm{~h}$ respectively, a sharp decrease of the cell density happened, indicating clear cell death caused by free DOX. Meanwhile, for those cells treated with peptide- $\mathrm{Fe}_{3} \mathrm{O}_{4} @ \mathrm{MSNs} / \mathrm{DOX}$ (Figure 4d), DOX was mainly distributed in cytoplasm at $4 \mathrm{~h}$. After incubation for another $4 \mathrm{~h}$, significant deformation of cells was observed and the red fluorescence from DOX in the nucleus was detected. After $12 \mathrm{~h}$ incubation, the fluorescence signal of DOX was concentrated in the nucleus and the signal of cytoplasm was almost invisible. Simultaneously, the cell density was also decreased considerably. On the contrary, the HT-1080 cells cultured with peptide-Fe $\mathrm{O}_{4} @ \mathrm{MSN} / \mathrm{DOX}+$ inhibitor exhibited 

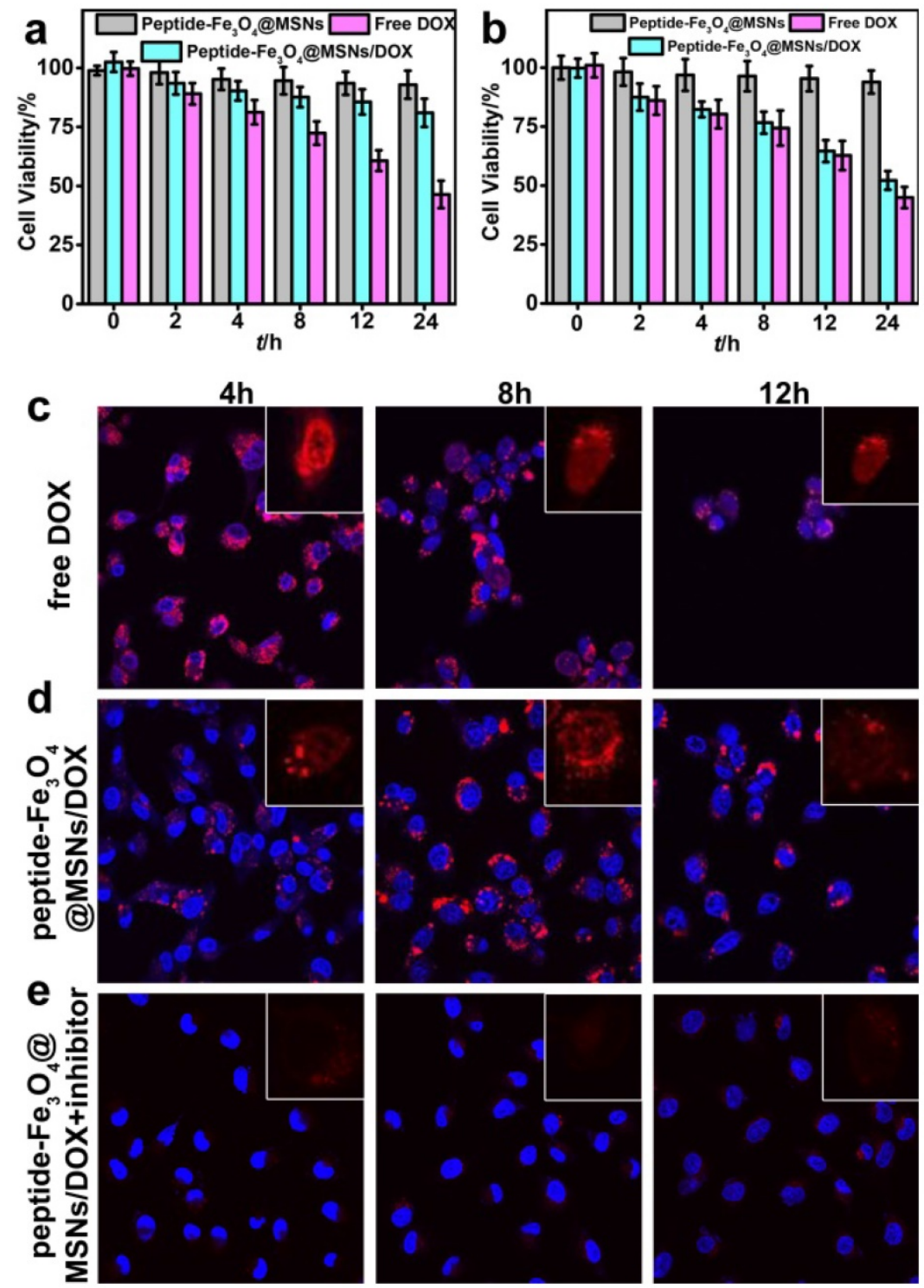

Figure 4. MTT assay of (a) NIH/3T3 cells and (b) HT-1080 cells with peptide-Fe $\mathrm{O}_{4} @ M S N s$, peptide-Fe $3 \mathrm{O}_{4} @ M S N s / D O X$ and free DOX. Confocal images of $\mathrm{HT}$-1080 cells incubated with free DOX (c), peptide- $\mathrm{Fe}_{3} \mathrm{O}_{4} @ M S N s / D O X(d)$ and peptide-Fe3 $\mathrm{O}_{4} @ M S N s / D O X+$ inhibitor (e) for different time (4 h, 8 h, 12 h). (Inset: confocal images of single cells, only DOX fluorescence signal)

very weak red fluorescence in the cytoplasm even after $12 \mathrm{~h}$ incubation time and the cell density almost did not change (Figure 4e). On the other hand, $\mathrm{NIH} / 3 \mathrm{~T} 3$ cells treated with peptide- $\mathrm{Fe}_{3} \mathrm{O}_{4} @ \mathrm{MSNs} /$ DOX did not show the red fluorescence in the first $4 \mathrm{~h}$ incubation and emitted very weak fluorescence signal after $12 \mathrm{~h}$, which was attributed to the low expression of MMP-2 enzyme (Figure S2). These results showed that peptide- $\mathrm{Fe}_{3} \mathrm{O}_{4} @ \mathrm{MSN} / \mathrm{DOX}$ nano-platform had high specificity to cancer cells with MMP-2 expression and limited toxicity to normal cells.

Before in vivo chemotherapy experiments, the biodistribution of peptide- $\mathrm{Fe}_{3} \mathrm{O}_{4} @ \mathrm{MSN} / \mathrm{DOX}$ was tested to evaluate the targeting capability based on the dual roles of magnetic targeting and enhanced permeabilization and retention (EPR) effect. Tumor-bearing mice were randomly divided into two groups ( 3 mice in each group) and both groups were intravenously injected with peptide- $\mathrm{Fe}_{3} \mathrm{O}_{4} @ \mathrm{MSNs}$. After $8 \mathrm{~h}$, both groups were humanely sacrificed to collect the organs and tumor tissues to check the distribution of iron ion in each part through ICP-OES. These results are summarized in Figure S3. Firstly, it is found that the nanocarriers accumulated in the reticuloendothelial organs like liver and spleen which was a common feature for nanomaterials in previous studies [42]. Secondly, tumor uptake of peptide$\mathrm{Fe}_{3} \mathrm{O}_{4} @$ MSNs through passive targeting was much lower than that treated with magnet. This phenomenon indicates that magnetic-guided delivery can effectively promote the enrichment of nanocarriers in tumor site and could be used to improve the treatment efficiency. 
Confocal images were used to evaluate the in vivo efficiency of enzyme-responsive release of peptide- $\mathrm{Fe}_{3} \mathrm{O}_{4} @ \mathrm{MSN} / \mathrm{DOX}$. In control experiment of mouse injected with free DOX (Figure S4), there was always a strong fluorescence signal no matter at $0.5 \mathrm{~h}$ or $2 \mathrm{~h}$. In contrast, for mouse injected with peptide- $\mathrm{Fe}_{3} \mathrm{O}_{4} @ \mathrm{MSN} / \mathrm{DOX}$, a very weak signal was detected at $0.5 \mathrm{~h}$. The signal kept increasing and was considerably strong at $2 \mathrm{~h}$ after injection, reflecting that the DOX was successfully and sufficiently released in vivo. However, if mouse was pre-treated with inhibitor, almost no fluorescence could be observed even after $2 \mathrm{~h}$ treatment. The in vivo results are well consistent with the findings of the confocal imaging and biodistribution analyses, which indicated the high efficiency of peptide- $\mathrm{Fe}_{3} \mathrm{O}_{4}$ @MSNs/DOX for magnetic-guided targeted delivery.

MRI is one important non-invasive imaging technique for tumor diagnosis. Herein, taking the magnetic property of $\mathrm{Fe}_{3} \mathrm{O}_{4}$ core, the peptide- $\mathrm{Fe}_{3} \mathrm{O}_{4}$ @MSNs/DOX system could serve as an efficient contrast agent for $\mathrm{T}_{2}$-weight MRI. The results are summarized in Figure $5 \mathrm{a}$ and $5 \mathrm{~b}$. It was found that for tumor site without magnet treatment (Figure 5a), only a faint darkening was detected at tumor area after injection for $3 \mathrm{~h}$. Simultaneously, for mice treated with additional magnet for $3 \mathrm{~h}$ (Figure 5b), a clear darkening was found, indicating that magnetic guiding could effectively induce the accumulation of drug nanocarriers to the tumor site.

To access the efficiency of in vivo chemotherapy, firstly we summarized the photos of mice after 21 days treatment of three parallel treatments in Figure $5 c$ which revealed quite different phenomenon. For mice injected with PBS only (the control), the tumor became significantly larger because of its continuous growing. Meanwhile, the tumor had smaller size for mice treated with peptide- $\mathrm{Fe}_{3} \mathrm{O}_{4} @ \mathrm{MSNs} / \mathrm{DOX}$. Amongst three tests, the peptide- $\mathrm{Fe}_{3} \mathrm{O}_{4} @ \mathrm{MSNs} / \mathrm{DOX}$ \& magnet group had the smallest tumor size, indicating the successful suppression of tumor growth. The time evolutions of body weight and tumor size were quantitatively evaluated and summarized in Figure $5 \mathrm{~d}$ and Figure 5e. During the treatment, the body weights almost kept being constants, except that slight decrease were observed a

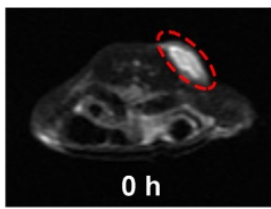

Control

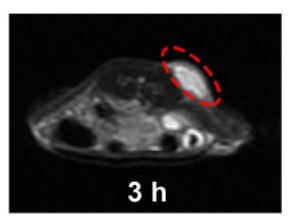

$3 \mathbf{h}$

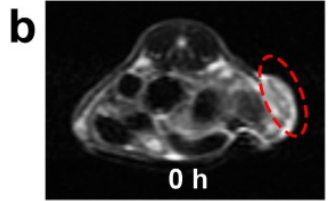

Peptide- $\mathrm{Fe}_{3} \mathrm{O}_{4} @ M S N s / D O X$

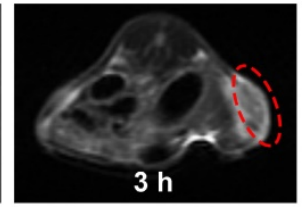

Peptide- $\mathrm{Fe}_{3} \mathrm{O}_{4} @ M S N s / D O X \& M a g n e t$

C
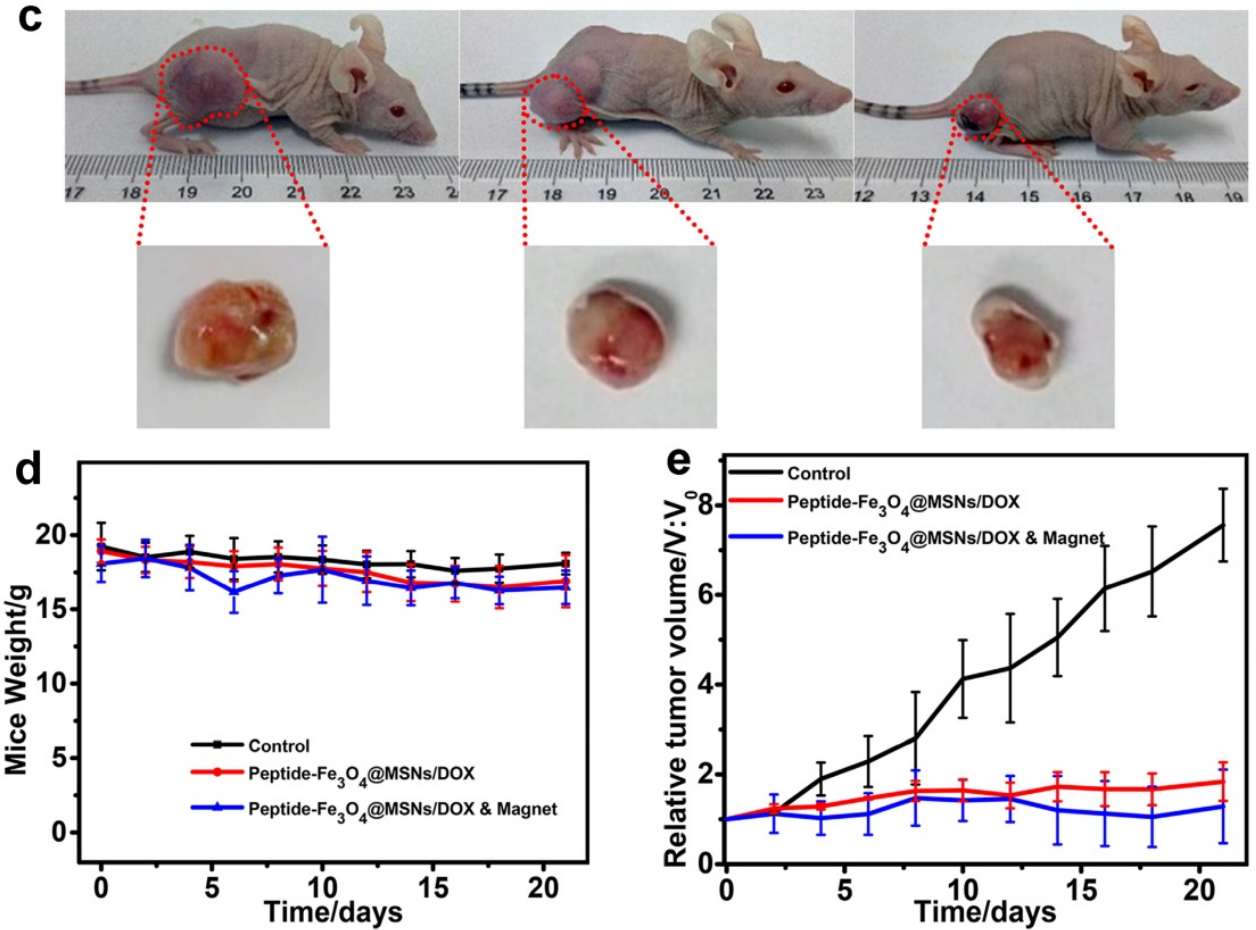

Figure 5. In vivo MRI ( $\mathrm{T}_{2}$-weight) images of tumor (a) treated with peptide-Fe $\mathrm{O}_{4} @ \mathrm{MSNs} / \mathrm{DOX}$ (images were taken $0 \mathrm{~h}$ and $3 \mathrm{~h}$ after injection), (b) treated with peptide- $\mathrm{Fe}_{3} \mathrm{O}_{4} @ M S N s / D O X \&$ magnet (images were taken $0 \mathrm{~h}$ after injection and $3 \mathrm{~h}$ magnet treatment at the tumor site). (c) Photographs of mice without treatment (left), with Peptide-Fe $\mathrm{O}_{4} @ M S N s / D O X$ (middle) and Peptide-Fe $\mathrm{O}_{4} @ M S N s / D O X$ \&Magnet (right) treatment for 21 days. The collected tumor tissues are depicted at the bottom of each figure. (d) Body weight curves of different groups for 21 days. (e) Tumor volume curves of different group for 21 days. 


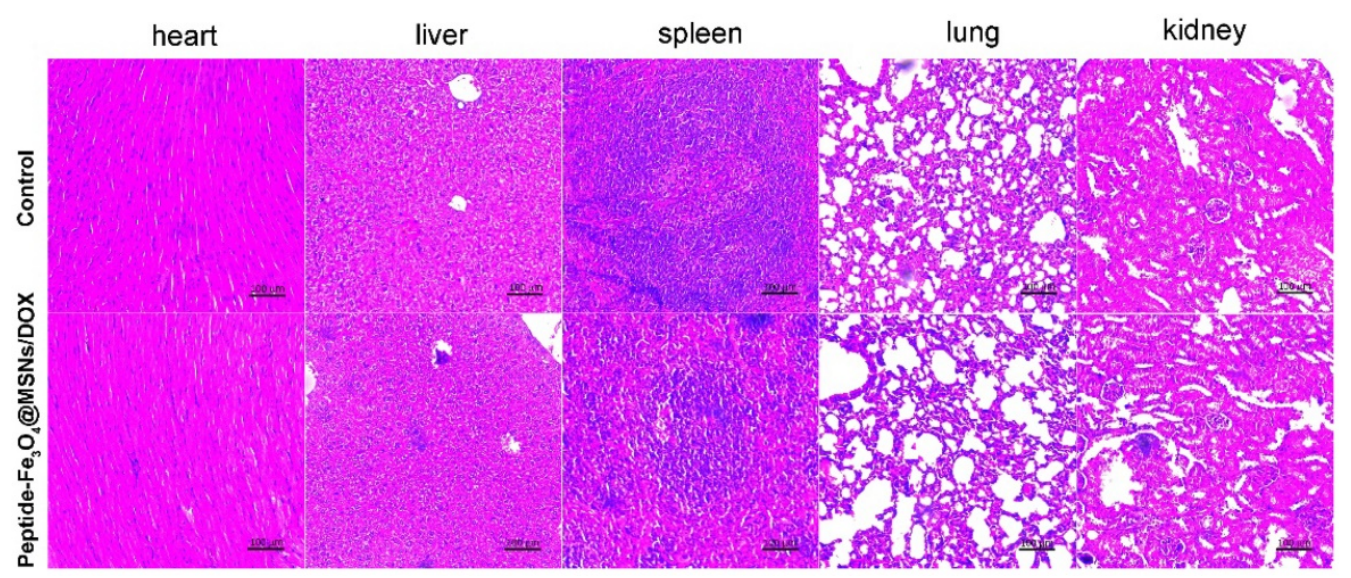

Figure 6. H\&E stained images of major organs harvested from control mice and mice treated with peptide-Fe $\mathrm{O}_{4} @ M S N s / D O X$, samples were collected three weeks after treatment.

for the two groups with the treatment of nanocarriers. This was mainly attributed to the side effect of chemotherapy. The tumor volumetric size of the control group increased dramatically to be more than 7 times of the primary size. On the contrary, the tumor only increased to be around 1.7 times for that treated with peptide- $\mathrm{Fe}_{3} \mathrm{O}_{4} @ \mathrm{MSN} / \mathrm{DOX}$. With additional magnet treatment, the tumor size was almost unchanged which was in line with the findings in Figure $5 \mathrm{c}$, meaning that peptide- $\mathrm{Fe}_{3} \mathrm{O}_{4} @ \mathrm{MSNs} / \mathrm{DOX}$ system could effectively inhibit tumor growth.

The main organs were then collected for pathological analysis to evaluate the in vivo toxicity of the nanocarrier system. As shown in Figure 6, only a slight edema was found in liver of mice treated with nanocarriers, indicating favourable biosafety in living system. This is benefitted to the silica coatings which are principally accepted to be safe. These results also confirmed the effectiveness of magnetic guided nanocarrier accumulation used as a supplementary approach for tumor treatment by magnetic nanoparticles.

\section{Conclusions}

In summary, an enzyme-responsive drug delivery nanosystem based on mesoporous silica coated magnetic iron oxide nanoparticles ( $\left.\mathrm{Fe}_{3} \mathrm{O}_{4} @ M S N s\right)$ has been constructed for MRI-guided cancer chemotherapy. By capping the mesoporous silica shell with MMP-2 substrate peptide, the functionalized peptide- $\mathrm{Fe}_{3} \mathrm{O}_{4} @ \mathrm{MSN}$ s can effectively encapsulate with anticancer drug. We demonstrated that, by adding the MMP-2 enzyme, the peptide on the nanoparticle surface could be efficiently cleaved to induce the drug molecules release both in vitro and in vivo. Moreover, the in vitro results indicated that the peptide- $\mathrm{Fe}_{3} \mathrm{O}_{4} @ M S N s / D O X$ own good biocompatibility and high specificity towards the cancerous cells with high MMP-2 enzyme expression. The in vivo experiments demonstrated that this magnetic nanoagent could efficiently accumulate at the tumor site through the treatment of an external magnetic field. MRI-guided chemotherapy experiments further revealed the successful inhibition of tumor growth. In addition to the cancer chemotherapy, this nanoagents could also be used as a general platform for the design of stimulus-responsive functional nanomaterials that find fruitful applications in biomedical related areas.

\section{Acknowledgements}

This work was supported by the National Natural Science Foundation of China (Grants 51402203, 21405108, 51628201), Postdoctoral Science Foundation of China (2016M601875), Postdoctoral Research Program of Jiangsu Province (1601167B), the Science and Technology Program of Suzhou (SYG201736). The Project is sponsored by State Key Laboratory of Radiation Medicine and Protection, Jiangsu Provincial Key Laboratory of Radiation Medicine and Protection, Jiangsu Key Laboratory for Carbon-Based Functional Materials \& Devices, Soochow University, the Priority Academic Program Development of Jiangsu Higher Education Institutions (PAPD).

\section{Supplementary Material}

Supplementary figures.

http://www.ntno.org/v02p0233s1.pdf

\section{Competing Interests}

The authors have declared that no competing interest exists.

\section{References}

(1) Ferrari M. Cancer nanotechnology: opportunities and challenges. Nat Rev Cancer. 2005; 5: 161-71.

(2) Peer D, Karp JM, Hong S, et al. Nanocarriers as an emerging platform for cancer therapy. Nat Nanotechnol. 2007; 2: 751-60. 
(3) Cheng L, Wang C, Feng L, et al. Functional nanomaterials for phototherapies of cancer. Chem Rev. 2014; 114: 10869-939.

(4) Sapsford KE, Algar WR, Berti L, et al. Functionalizing nanoparticles with biological molecules: developing chemistries that facilitate nanotechnology. Chem Rev. 2013; 113: 1904-2074.

(5) Jochum FD, Theato P. Temperature- and light-responsive smart polymer materials. Chem Soc Rev. 2013; 42: 7468-83.

(6) Cobo I, Li M, Sumerlin BS, et al. Smart hybrid materials by conjugation of responsive polymers to biomacromolecules. Nat Mater. 2015; 14:143-59.

(7) Dai L, Liu J, Luo Z, et al. Tumor therapy: targeted drug delivery systems. J Mater Chem B. 2016; 4: 6758-72.

(8) Yang Y, Velmurugan B, Liu X, et al. NIR Photoresponsive Crosslinked Upconverting Nanocarriers Toward Selective Intracellular Drug Release. Small. 2013; 9: 2937-44

(9) Cheng X, Yong Y, Dai Y, et al. Enhanced Radiotherapy using Bismuth Sulfide Nanoagents Combined with Photo-thermal Treatment. Theranostics. 2017; 7: 4087-98.

(10) Lv R, Yang P, He F, et al. A yolk-like multifunctional platform for multimodal imaging and synergistic therapy triggered by a single near-infrared light. ACS Nano. 2015; 9: 1630-47.

(11) Yuan Y, Ding Z, Qian J, et al. Casp3/7-Instructed Intracellular Aggregation of $\mathrm{Fe}_{3} \mathrm{O}_{4}$ Nanoparticles Enhances $\mathrm{T}_{2}$ MR Imaging of Tumor Apoptosis. Nano Lett. 2016; 16: 2686-91.

(12) Choi YR, Lee B, Park J, et al. Enzyme-Responsive Procarriers Capable of Transporting Chloride Ions across Lipid and Cellular Membranes. J Am Chem Soc. 2016; 138: 15319-22.

(13) Popat A, Ross BP, Liu J, et al. Enzyme-responsive controlled release of covalently bound prodrug from functional mesoporous silica nanospheres. Angew Chem Int Ed Engl. 2012; 51: 12486-9.

(14) Zhang H, Fei J, Yan X, et al. Enzyme-Responsive Release of Doxorubicin from Monodisperse Dipeptide-Based Nanocarriers for Highly Efficient Cancer Treatment In Vitro. Adv Funct Mater. 2015; 25: 1193-204.

(15) Sun T, Zhang YS, Pang B, et al. Engineered nanoparticles for drug delivery in cancer therapy. Angew Chem Int Ed Engl. 2014; 53: 12320-64.

(16) Weissleder R, Tung $\mathrm{CH}$, Mahmood $\mathrm{U}$, et al. In vivo imaging of tumors with protease-activated near-infrared fluorescent probes. Nat Biotechnol. 1999; 17: 375-8.

(17) Olson ES, Jiang T, Aguilera TA, et al. Activatable cell penetrating peptides linked to nanoparticles as dual probes for in vivo fluorescence and MR imaging of proteases. Proc Natl Acad Sci U S A. 2010; 107: 4311-6.

(18) Lecaille F, Kaleta J, Brömme D. Human and parasitic papain-like cysteine proteases: their role in physiology and pathology and recent developments in inhibitor design. Chem Rev. 2002; 102: 4459-88.

(19) Zheng F, Zhang P, Xi Y, et al. Peptide-mediated core/satellite/shell multifunctional nanovehicles for precise imaging of cathepsin B activity and dual-enzyme controlled drug release. NPG Asia Mater. 2017; 9: e366.

(20) Yang Y, Aw J, Chen K, et al. Enzyme-responsive multifunctional magnetic nanoparticles for tumor intracellular drug delivery and imaging. Chem Asian J. 2011; 6: 1381-9.

(21) Kessenbrock K, Plaks V, Werb Z. Matrix metalloproteinases: regulators of the tumor microenvironment. Cell. 2010; 141: 52-67.

(22) Ji T, Li S, Zhang Y, et al. An MMP-2 Responsive Liposome Integrating Antifibrosis and Chemotherapeutic Drugs for Enhanced Drug Perfusion and Efficacy in Pancreatic Cancer. ACS Appl Mater Interfaces. 2016; 8: 3438-45.

(23) Huang $S$, Shao $K$, Kuang $Y$, et al. Tumor targeting and microenvironment-responsive nanoparticles for gene delivery. Biomaterials. 2013; 34: 5294-302.

(24) Peng ZH, Kopeček J. Enhancing Accumulation and Penetration of HPMA Copolymer-Doxorubicin Conjugates in 2D and 3D Prostate Cancer Cells via iRGD Conjugation with an MMP-2 Cleavable Spacer. J Am Chem Soc. 2015; 137: 6726-9.

(25) Zou Z, He X, He D, et al. Programmed packaging of mesoporous silica nanocarriers for matrix metalloprotease 2-triggered tumor targeting and release. Biomaterials. 2015; 58: 35-45.

(26) Singh RK, Patel KD, Leong KW, et al. Progress in Nanotheranostics Based on Mesoporous Silica Nanomaterial Platforms. ACS Appl Mater Interfaces. 2017; 9: 10309-37.

(27) Li X, Zhou L, Wei Y, et al. Anisotropic growth-induced synthesis of dual-compartment Janus mesoporous silica nanoparticles for bimodal triggered drugs delivery. J Am Chem Soc. 2014; 136: 15086-92.

(28) Li Y, Li N, Pan W, et al. Hollow Mesoporous Silica Nanoparticles with Tunable Structures for Controlled Drug Delivery. ACS Appl Mater Interfaces. 2017; 9: 2123-9.

(29) Hu JJ, Lei Q, Peng MY, et al. A positive feedback strategy for enhanced chemotherapy based on ROS-triggered self-accelerating drug release nanosystem. Biomaterials. 2017; 128: 136-46.

(30) Qu Q, Ma X, Zhao Y. Anticancer Effect of a-Tocopheryl Succinate Delivered by Mitochondria-Targeted Mesoporous Silica Nanoparticles. ACS Appl Mater Interfaces. 2016; 8: 34261-9.

(31) Sreejith S, Ma X, Zhao Y. Graphene oxide wrapping on squaraine-loaded mesoporous silica nanoparticles for bioimaging. J Am Chem Soc. 2012; 134: 17346-9.

(32) Nakamura T, Sugihara F, Matsushita H, et al. Mesoporous silica nanoparticles for ${ }^{19} \mathrm{~F}$ magnetic resonance imaging, fluorescence imaging, and drug delivery. Chem Sci. 2015; 6: 1986-90.
(33) Lee JE, Lee $\mathrm{N}$, Kim $\mathrm{H}$, et al Uniform mesoporous dye-doped silica nanoparticles decorated with multiple magnetite nanocrystals for simultaneous enhanced magnetic resonance imaging, fluorescence imaging, and drug delivery. J Am Chem Soc. 2010; 132: 552-7.

(34) Hu Y, Hu H, Yan J, Zhang C, Li Y, Wang M, et al. Multifunctional Porous Iron Oxide Nanoagents for MRI and Photothermal/Chemo Synergistic Therapy. Bioconjugate Chem. 2018; 29: 1283-90.

(35) Long MJ, Pan Y, Lin HC, et al. Cell compatible trimethoprim-decorated iron oxide nanoparticles bind dihydrofolate reductase for magnetically modulating focal adhesion of mammalian cells. J Am Chem Soc. 2011; 133: 10006-9.

(36) Gorelikov I, Matsuura N. Single-step coating of mesoporous silica on cetyltrimethyl ammonium bromide-capped nanoparticles. Nano Lett. 2008; 8: 369-73.

(37) Li N, Yu Z, Pan W, et al. A Near-Infrared Light-Triggered Nanocarrier with Reversible DNA Valves for Intracellular Controlled Release. Adv Funct Mater. 2013; 23: 2255-62.

(38) Mathur S, Barth S, Werner U, et al. Chemical Vapor Growth of One-dimensional Magnetite Nanostructures. Adv Mater. 2008; 20: 1550-4

(39) Laurent S, Forge D, Port M, et al. Magnetic iron oxide nanoparticles: synthesis, stabilization, vectorization, physicochemical characterizations, and biological applications. Chem Rev. 2008; 108: 2064-110.

(40) Zhang J, Yuan ZF, Wang Y, et al. Multifunctional envelope-type mesoporous silica nanoparticles for tumor-triggered targeting drug delivery. J Am Chem Soc. 2013; 135: 5068-73.

(41) Chen AM, Zhang M, Wei D, et al. Co-delivery of doxorubicin and Bcl-2 siRNA by mesoporous silica nanoparticles enhances the efficacy of chemotherapy in multidrug-resistant cancer cells. Small. 2009; 5: 2673-7.

(42) Wang Y, Wu Y, Liu Y, et al. BSA-Mediated Synthesis of Bismuth Sulfide Nanotheranostic Agents for Tumor Multimodal Imaging and Thermoradiotherapy. Adv Funct Mater. 2016; 26: 5335-44. 